\title{
Mid-20th Century Colombian Vaults. A Contemporary Tradition
}

\author{
Julián García $^{1(\mathbb{凶})}$, Fernando Magdalena ${ }^{1}$, and Juan M. Medina ${ }^{2}$ \\ 1 Architectural Building Department, \\ Universidad Politécnica de Madrid - UPM, Madrid, Spain \\ \{julian.garciam, fernando.magdalena\}@upm.es \\ 2 Facultad de Arquitectura y Diseño, Universidad de los Andes, \\ Bogotá, Colombia \\ jm.medinad@uniandes.edu.co
}

\begin{abstract}
Despite their extraordinary interest, Colombian vaults of the central third of the 20th century have been rarely studied. Some concrete vaulted shells of very specific buildings, such as the ones of the Cartagena baseball stadium, are well-known, but more inconspicuous vaults for the structures of smaller buildings remain undervalued -especially structures for single-family houses, which were then a laboratory for testing all types of variants of lightweight vaults, some of which would be used later in other major constructions. An important milestone in this type of construction is the Casa Pizano, a building that can be traced today due to a peculiar coincidence that made its vaults especially influential in the history of modern architecture: Le Corbusier rediscovered tile vaults in this Bogota house, and later used a similar technique in some buildings that would be very influential in turn. But local architects were at that time using not only tile vaults but also many other vaulted systems, from concrete shells to reinforced ceramics. This paper will highlight the most significant examples of small-scale vaulted structures built in the Colombia of the $1950 \mathrm{~s}$, and establish a possible narrative for these constructions. To achieve this, a basic taxonomy will be first drawn up; then three examples of representative buildings of the main constructive systems will be studied; and, finally, a brief analysis of the impact of these examples in the construction of vaulted buildings throughout Latin America will be attempted.
\end{abstract}

Keywords: Masonry $\cdot$ Tile vaults $\cdot$ Reinforced ceramics $\cdot$ Concrete vaults Colombia

\section{Introduction}

Le Corbusier visited in Colombia in 1950 [1] a now demolished Colombian building, the Casa Pizano (Pizano 1950) built by the local architect Francisco Pizano de Brigard. The house inspired Le Corbusier's two buildings covered with tile vaults: the houses Sarabhai (1955) and Jaoul (1955) that would be very influential in turn [2]. However, the Casa Pizano was just one of the many modern Latin American buildings covered with lightweight vaults in the mid-twentieth century: tile vaults coexisted with many other systems of lightweight vaulting or laminar construction, from reinforced ceramics 
to concrete vaulted shells. Those were years of extraordinary effervescence of experimental structural solutions in the area.

There is no taxonomic study that relates the different techniques that were tested, with better or worse fortune, in those years. Only in Colombia hundreds of lightweight vaults were built in the $50 \mathrm{~s}$, using very different techniques. Many of these techniques keep some common characteristics (require similar forms, and provide minimum thicknesses) but they also have great differences with regard to their constituent materials, their structural behaviour or the processes necessary for their construction. The study of these systems as a whole is not justified by their formal similarity (which, on the other hand, does not entail similar structural behaviour) but because they were often mixed: there are cases of neighbourhoods in which identical buildings were built with different techniques; others of buildings designed with one technique but finally built with another; and others in which different techniques were used, literally, superimposed. The starting hypothesis of this article is that this technical promiscuity was the origin of the complex catalogue of solutions that emerged in Latin American construction in the following decades.

In the following the generic "lightweight vaults", however imprecise it may be, will be used to refer to the group of these thin vaulted systems -as opposed to traditional masonry vaults, usually much heavier and thicker- and each system will be named after the terms included in Table 1 , adding a nuance when necessary.

Table 1. Basic taxonomic relationship of light vaults used in Latin America in the central decades of S. XX.

\begin{tabular}{l|l|l|l|l|l}
\hline \multicolumn{2}{l|}{ Ceramics } & \multicolumn{2}{l|}{ Concrete shells } & \multicolumn{2}{l}{ Mixed techniques } \\
\hline A & Tile vaults & D & $\begin{array}{l}\text { Conventional concrete } \\
\text { shells }\end{array}$ & H & $\begin{array}{l}\text { Cladded concrete } \\
\text { shells }\end{array}$ \\
\hline \multicolumn{2}{l}{ Reinforced Ceramics } & E & Precast concrete shells & I & $\begin{array}{l}\text { Shells on brick } \\
\text { formwork }\end{array}$ \\
\hline B & $\begin{array}{l}\text { Conventional R. } \\
\text { Ceramics }\end{array}$ & F & Gunite shells & J & Precast brick vaults \\
\hline C & $\begin{array}{l}\text { R. Ceramics with special } \\
\text { blocks }\end{array}$ & G & Hollow concrete shells & K & $\begin{array}{l}\text { Other vaults and } \\
\text { shells }\end{array}$ \\
\hline
\end{tabular}

Three examples are described below, all of single-family house structures -an interesting architectural typology since, mainly due to their affordable scale, it constituted a laboratory for testing new techniques. These are the Casa Pizano (A, tile vaults), the Quiroga Neighbourhood (E, precast concrete shells) and Bermúdez-Samper (C, reinforced ceramics with special blocks). These cases were chosen (in increasing order of constructive complexity) because they exemplify the creativity of local technicians and because they can be understood as the basis for the development of more complex constructions with mixed techniques. 


\section{Masonry Vaults}

\subsection{Tile Vaults in Colombia}

Unlike other areas of Latin America [3] Colombia has no record of vaults in vernacular construction. The technique of tile construction, usual in the tradition of the Mediterranean, was unusual in Bogotá, so the most plausible reason for its use in the construction of the Casa Pizano was the close relationship of Pizano with an architect and builder of Spanish origin, Fernando Murtra, who built various vaults in the area. "Even the workers who worked with him were Catalans" [4].

\subsection{The Casa Pizano}

The Casa Pizano was built with tile vaults, which made up all the elements of its horizontal structures. Unfortunately, the building does not exist anymore; however, its constructive configuration is well known. (Figure 1C) The building (Figs. 1A and B) consisted of three areas separated by loadbearing walls. All the horizontal structures were built with traditional tile vault construction techniques, with two brick layers (Figs. 2A and B). The vaults rested on concrete edge beams by means of steel tension rods to alleviate the thrust of the masonry vaults. The structure of the Casa Pizano was not exactly new, but it included a strategy that was later very influential. Pizano used segmental vaults, with a span/rise ratio of approximately $1 / 8$. These vaults were cablestayed only in the lateral bays (as for the central bay cables were logically considered unnecessary) so the central ones were free, since that thrust was retained on the sides. It should be noted that Pizano was fully aware of the structural behaviour of the vaults he had built in his house. "In that house we rehearsed, I believe that for the first time in Colombia, the modern construction of thrust brick vaults. The design included three vaults and had a slender staircase inside, made of thrust tiles" [5].

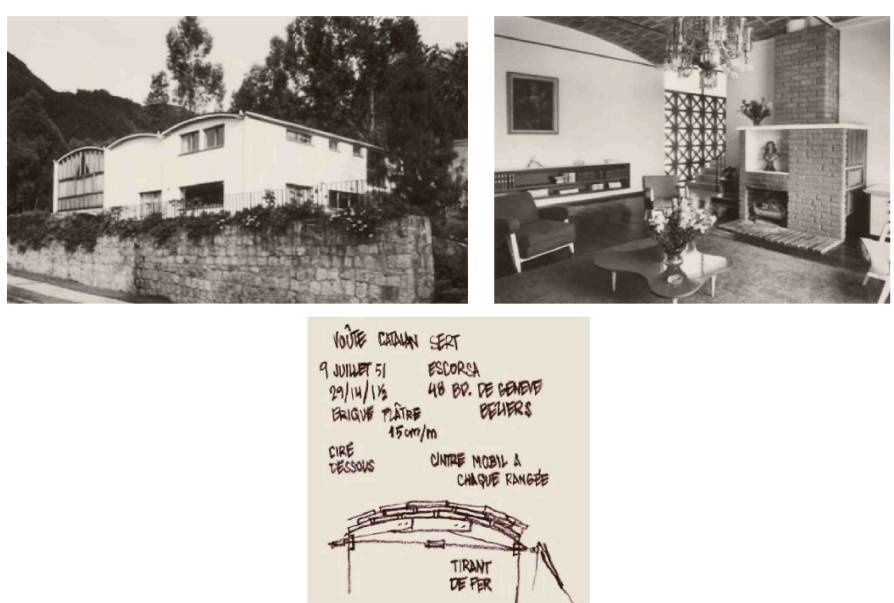

Fig. 1. A. General view of the Casa Pizano. B. Casa Pizano. Interior. Both in PROA Magazine no 42, 1950. Bogotá. C. Authors' copy of Le Corbusier sketchbook E21 p. 512. 

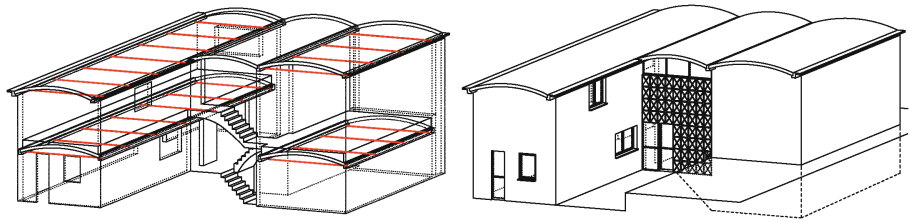

Fig. 2. A. Casa Pizano. Axonometric view. B. Axonometric view of the cable-stayed structures. Both by the authors.

This structural scheme set a precedent that would later be used in different local buildings with vaults. Thus, the lateral bays would in the future have a differentiated treatment, either by means of bracing or by reorienting them -rotating them $90^{\circ}$ so that they would absorb the thrust, acting as buttresses.

\section{Concrete Shells}

\subsection{Precast Concrete. The Patents of Vacuum Concrete}

Colombian architects were also pioneers in the construction of lightweight concrete shells, especially with vacuum concrete, a system patented in the $40 \mathrm{~s}$ of the 20th century. The architect Álvaro Ortega took over the dealership of K.P. Billner's (originally registered in the United States in 1948) in the early 50's. The system was designed to build all types of surfaces easily, but Ortega applied it especially in the construction of vaulted structures of minimum thickness, with the intention of adjusting costs in two ways: the industrialization of the production process and the reduction of necessary construction materials. The system allowed reducing the necessary amount of concrete and at the same time avoiding hydrophobic mortars, since vacuum concrete was considered sufficiently watertight to conform the complete roofing of the building.

Using this system Ortega built (as an architect, but also as a contractor through his own company, Vacuum Concrete of Colombia) several structures: the Clark Chiclet Factory (Pizano 1953) or the Colombia Wool Factory (Ortega 1955). He also had tried vacuum concrete on a smaller scale in residential buildings, such as the Casa BermúdezSamper (Bermudez 1953) or the Quiroga neighbourhood (1952) (Figs. 3A and B).
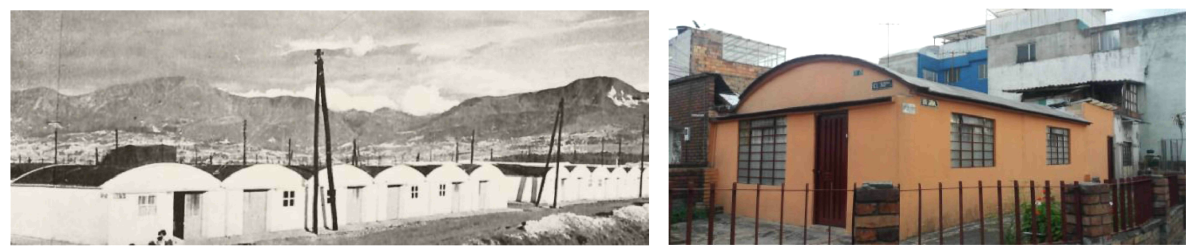

Fig. 3. A. View of the Quiroga Neighbourhood. In PROA Magazine no 71, 1953. Bogotá. B. Current state of the neighbourhood. Photo: Juan Manuel Medina. 


\subsection{The Quiroga Neighbourhood}

The construction of the Quiroga neighbourhood involved almost all the protagonists of Colombian vault construction. Based on the urban planning of J.L. Sert, in which Pizano collaborated, the works began in 1951, with Jorge Gaitán still a member of the management of the Territorial Credit Institute, and was built, for the most part, with Ortega's vacuum concrete systems. One of the areas in which the neighbourhood was planned, the section Urdaneta Arbeláez (García and Moreno 1953) was described by the authors in these terms: "the contractors, young architects, have used several procedures here: the Catalan system with ceramic 'locetas' [...]; concrete vaults and the prefabricated system of the Vacuum Concrete in Colombia" [6].

Vacuum concrete shells required relatively little machinery for on-site construction: "In practice, necessary elements to operate this technique are a vacuum pump, a sedimentation tank and the piping to create vacuum in the spiracles" [7] (Fig. 4A). Better concrete meant also little need for steel: just a bi-directional reinforcement, designed almost exclusively for tensions during assembly: "by reducing the watercement ratio, an increase in compressive strength is achieved. This increase [...] reaches, after 28 days, a figure of $30 \%$. This ratio will remain constant thereafter". The waterproofing capacity of vacuum concrete was also studied: "Of the many tests carried out to hydraulic pressure $[\ldots]$ it is deduced that the increase in impermeability is of $500 \% "$
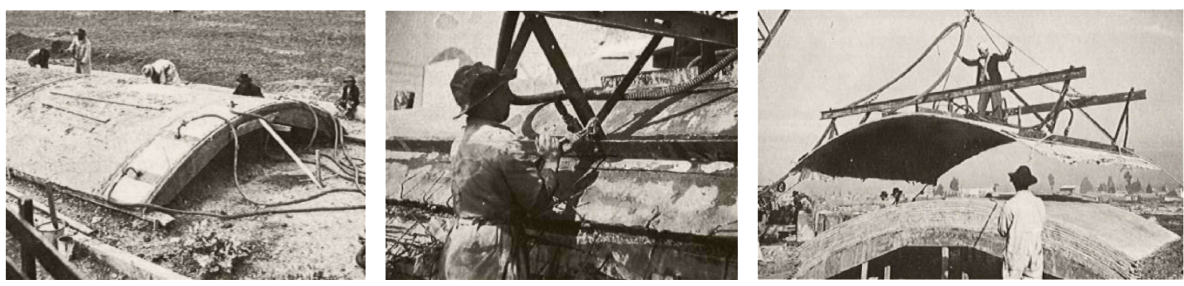

Fig. 4. A. View of the vacuum pump. B. Installation of the lifting system. C. Lifting of one of the shells. All in PROA Magazine no 71, 1953. Bogotá.

Pizano described the assembly process of a similar building, the Clark Chiclet Factory. "All the walls were laid on the floor, one on top of the other, and then with a suction system and a crane they were hoisted to their place, assembling them like a Lego (Figs. 4B and C). That was the process brought to Colombia by Ortega and Solano -as well as ingenious, very economic, since it reduced the number of formworks, pouring all the concrete of one vault over the previous like a deck of cards, allowing the installation at great speed". The system entailed serious problems: "unfortunately, due to the same virtue of the material, and of course for economy, walls were very thin and the joint problems were never satisfactorily resolved". The process was also "distressing $[\ldots]$ because those vaults were lifted with a compression suck that took all the air out of them. That suction cup was a little primitive, [...] it had leaks and when the vault was five or six meters high $[\ldots]$ air entered it and one did not rest until 
the piece was left in its place. [...] It was a pity that the process was not perfected, since it would have allowed building with interesting prices".

\section{Variants on Reinforced Ceramics}

\subsection{From Reinforced Ceramics to the Hat Brick}

Reinforced brick-shell structures were used surprisingly early in several large-scale Colombian buildings [8]. From the beginning of the $50 \mathrm{~s}$, different ceramic blocks began to be used to lighten the shells of the C /68 Bus Station (Solano, Ortega and G. Zuleta 1951) or the $5 \mathrm{~cm}$ thick sinusoids of the Volkswagen Building (Violi and G. Zuleta 1955). These structures were built after Casa Berlingieri (Bonet and Dieste 1947) but before the large reinforced ceramic buildings designed by Eladio Dieste.

Some Colombian structures were built with this technique and a special ceramic block: the hat brick, a ceramic piece patented by Jorge Gaitán. It combines (Fig. 5A) a square base with a cylinder open to the interior, designed to allow the reinforcement to be assembled in several directions, lightening the structure at the same time. The hat brick was used in buildings such as the Bogotá Comedy Theater (Fig. 5B, Gaitán 1954), the Río or Girardot Theater (Gaitán 1953) or the Church of San Cristobal, in Bogotá (Gaitán 1954-67). Gaitán also experimented with the hat brick in the structure of his own house, the Casa Gaitán Cortés (1953) (Fig. 5C).
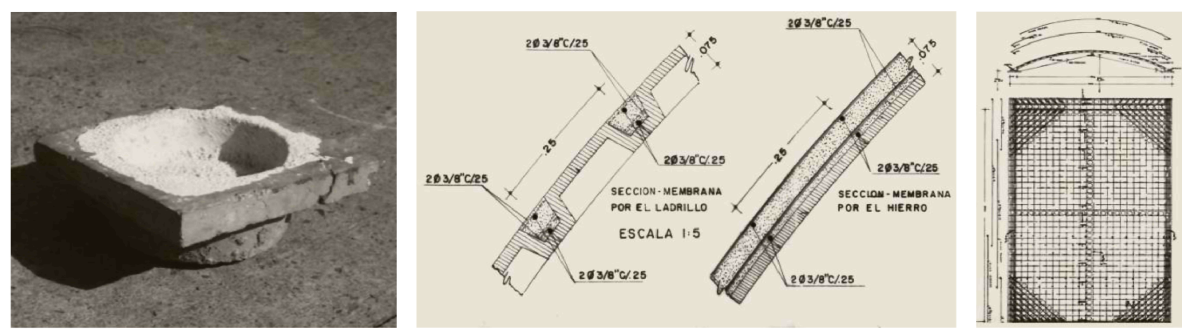

Fig. 5. A. Inverted Hat Brick. B. Detail of the San Cristobal Church (Gaitán 1954). C. Plan of the Casa Gaitán. All in Gutiérrez, N. 2011. "La casa de Jorge Gaitán”. Instituto de patrimonio cultural. Bogotá.

\subsection{The Casa Gaitán Cortés}

The Casa Gaitán Cortés [9] has similarities with the Casa Pizano. The upper roof of the building shows out a vaulted form (Fig. 6A), in this case of hat brick reinforced ceramics (Fig. 6C). The standard bidirectional reinforcement is complemented at the corners by a series of bars at $45^{\circ}$ to eliminate the braces, which would have generated an uncomfortable space -given the height of the vaulted area (Fig. 6B). The thrust of the central area of the vault is assumed by an edge beam and the aforementioned corner reinforcement. 

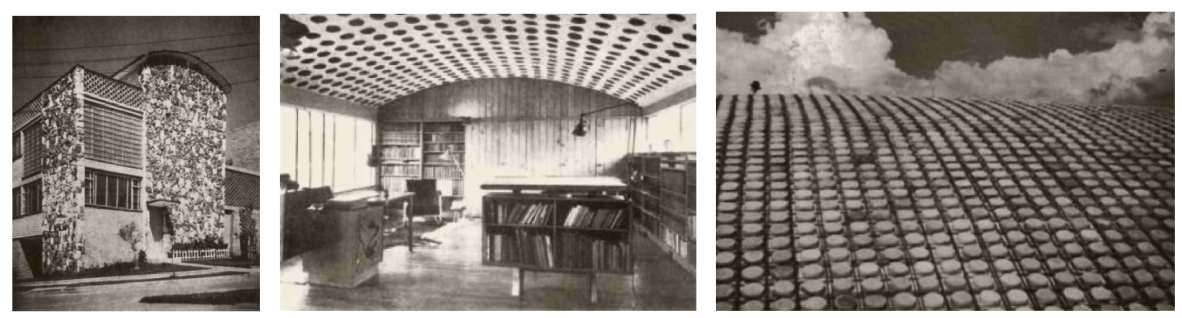

Fig. 6. A. View of the Casa Gaitán. B. The vault from the inside. C. Construction of the vault. All in Gutiérrez, N. 2011. "La casa de Jorge Gaitán”. Instituto de patrimonio cultural. Bogotá.

The details of the structure of the Church of San Cristóbal (again Fig. 5B) allow understanding the virtues of the system. The hat brick not only lightens the structure, but also allows a longitudinal and transversal reinforcement (and with it the performance of the structure as a conventional slab) and facilitates the insertion of the aforementioned reinforcement at $45^{\circ}$ at the corners. These corners become, in a way, special pendentives that, connected by the edge beam (Fig. 5C), collect the compressions that the central oval can generate. The design of these edge beams is also inherited from the Casa Pizano.

There are no details to illustrate the construction process, but the descriptions that are kept emphasize the simplicity of the installation and the lightness of the necessary formwork: "With guadua (a variant of local bamboo) a lightweight formwork was built. I was crossed with thin iron rods and between them hat bricks were installed. Then concrete was poured, a very thin layer of five centimetres" [10].

\section{Antecedents and Consequents of the Colombian Vaults of the 50's}

Establishing causal relationships between buildings covered with vaults in Latin America in the middle decades of the 20th century is complicated. Many variables should be considered: different architectural programs, different available technologies, etc. However, some connections between the aforementioned buildings and other previous and subsequent structures can be proposed to help fit the previous tentative taxonomy.

Regarding tile vaults, and in addition to the mentioned importance of Murtra's company, the influence of José Luis Sert should be considered. Sert's Casas del Garraf (Sert 1935) are the first antecedent of modern recycling of these vaults, as they already incorporated most of the invariants that would later appear in modern vaulted buildings. After the Casa Pizano, several Colombian architects used tile vaults in other buildings or projects (Casas el Retiro (Pizano et al. 1951)) but the use of this technique was quickly abandoned in Colombia. Outside the country there were numerous experiences, though, from the Art Schools of Havana (Porro 1966) to the countless constructions of architects of Tucumán such as Eduardo Sacriste [11]. 
Some later houses were built imitating the aesthetics of exposed brick of Casa Pizano -although without thrust vaults. Pizano himself used this technique in the House of Ignacio Gómez (Pizano, Pradilla and Caro in 1955) or his own second home (Pizano 1960): concrete shells or slabs decorated with ceramic tiles on the underside; from a structural point of view they were just concrete shells but inside they were finished off by a ceramic tiling.

Antecedents for the Colombian reinforced ceramic buildings start from the Casa Berlingieri (Bonet 1947) -professedly the first building to use reinforced ceramics-, whose influence flies over all the constructions studied in this paper. Almost at that time Colombian engineers were using advanced laminar solutions on the roofs of large buildings. González Zuleta, for example, built as early as in 1951 [12] the vaults of the Bus Station of C/68 (Solano, Ortega and G. Zuleta) with reinforced ceramics; Pizano would later collaborate later with Zuleta in another vaulted buildings with reinforced ceramics, the Super Rayo Market (1954) (Table 2).

Prefabricated concrete shells did not have the projection that Ortega would have liked, but they were the inspiration of several subsequent initiatives of great interest -in

Table 2. Examples of vaulted buildings in Colombia in the 50's. Not all the systems included in Table 1 were used in the area.

\begin{tabular}{|c|c|c|c|c|c|}
\hline & & & 1944-1949 & $1950-1954$ & $1955-1959$ \\
\hline Cer & A & Tile vaults & - & $\begin{array}{l}\text { Casa Pizano } \\
(1950)\end{array}$ & $\begin{array}{l}\text { Casa Celis } \\
\text { (1956) }\end{array}$ \\
\hline \multirow[t]{2}{*}{$\begin{array}{l}\text { Reinf. } \\
\text { Ceram. }\end{array}$} & B & $\begin{array}{l}\text { Conventional } \\
\text { reinforced } \\
\text { ceramics }\end{array}$ & & $\begin{array}{l}\text { Bus Station } \\
\text { C/68 (1951) }\end{array}$ & $\begin{array}{l}\text { Supermercado } \\
\text { Rayo (1955) } \\
\text { VW Workshop } \\
\text { (1955) }\end{array}$ \\
\hline & $\mathrm{C}$ & $\begin{array}{l}\text { R. Ceramics with } \\
\text { special blocks }\end{array}$ & - & $\begin{array}{l}\text { Río Theatre } \\
\text { (1953) } \\
\text { La Comedia } \\
\text { Theatre (1954) }\end{array}$ & $\begin{array}{l}\text { Casa Gaitán } \\
\text { Cortés (1955) } \\
\text { S.Cristóbal } \\
\text { Church (54-67) }\end{array}$ \\
\hline \multirow[t]{2}{*}{ Concrete } & D & Concrete shells & $\begin{array}{l}\text { Girardot } \\
\text { Market } \\
\text { (1945) } \\
\text { Cartagena } \\
\text { Stadium } \\
(1947)\end{array}$ & $\begin{array}{l}\text { Gim. Moderno } \\
\text { Chapel (1954) } \\
\text { Techo } \\
\text { Hippodrome } \\
\text { (1954) }\end{array}$ & $\begin{array}{l}\text { N.S. Fatima } \\
\text { Church (1956) } \\
\text { Cundinamarca } \\
\text { Chapel (57) }\end{array}$ \\
\hline & $\mathrm{E}$ & $\begin{array}{l}\text { Precast concrete } \\
\text { shells }\end{array}$ & - & $\begin{array}{l}\text { Quiroga } \\
\text { Neighbourhood } \\
\text { (52) } \\
\text { Casa Bermúdez } \\
\text { (1952) }\end{array}$ & $\begin{array}{l}\text { Wool Factory } \\
\text { (1955) } \\
\text { Blocks Factory } \\
(1955)\end{array}$ \\
\hline Mix & $\mathrm{H}$ & $\begin{array}{l}\text { Concrete shells } \\
\text { with cladding }\end{array}$ & - & - & $\begin{array}{l}\text { Casa Ignacio } \\
\text { Gómez (1955) } \\
\text { Casa Pizano II } \\
(1960)\end{array}$ \\
\hline
\end{tabular}


addition to those already mentioned. The Mexican Unidad Clemente Orozco (González 1959) used similar strategies, but with trough vaults; a few years later, the Argentinean experiences of the Uruguayan Kalemkerian (Fig. 7A) combined precast and tile vault techniques in buildings such as the headquarters of the Navy Arsenal (1976) [13]. The possibilities of combining reinforced ceramics and pieces of special shapes had continuity in different experiences. One of the best-known cases is the Municipal Cylinder of Montevideo (Viera 1956-67), with radial elements, but many other initiatives with ceramic elements of various forms were used in those years throughout Latin America.
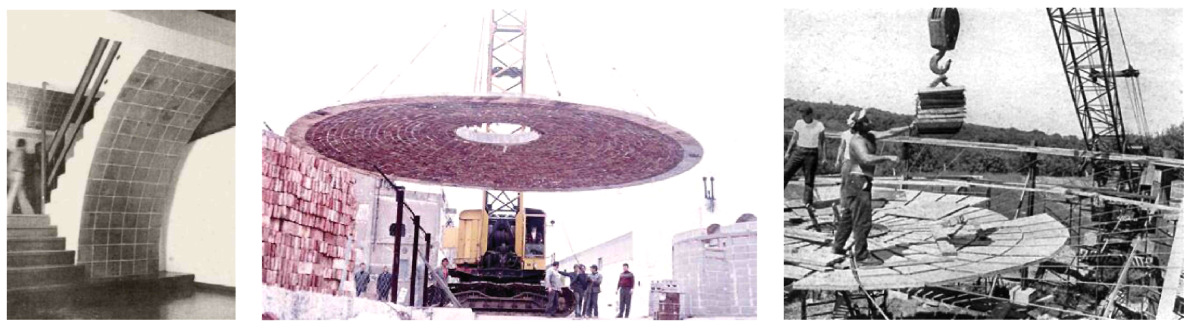

Fig. 7. A. Clérico House (Sacriste 1958). In Sacriste, E. 1977. "Casas con bóvedas”. Espacio Editora. Buenos Aires. B. Army Arsenal (Kalemkerian 1976). In Kalemkerian, M. 1976 "Nuevas instalaciones para la Armada", Informes de la Construcción no 284. CSIC-IETCC, Madrid. C. Municipal Cylinder (Viera 1956). In Cassinello, F. 1974 "Hormigonería”. Ed. Rueda, Madrid.

\section{Conclusions}

The aforementioned buildings are just examples of the trend towards innovation in vaulted construction that was put into practice throughout Latin America in the middle decades of the 20th century. The analysis of these examples shows how the structures built in Colombia in the 50's were to be extremely influential on systems developed later in other areas. The interaction of systems that took place in that country encouraged the creativity that characterized the construction of structures in Latin America in the following decades.

The analysis of Table 2 shows that the mentioned systems were used there in a tentative, non-evolutionary way. That is to say: unlike in other nearby areas (such as northern Argentina, where the tile vault was gradually transformed into reinforced ceramics), there was no continuous evolution there, but an intention to test, through proof and error, the possibilities and limitations of the different systems available.

Official historiography tends to attribute to reinforced ceramics a status of independent technique, oblivious to any other system close in time. According to this approach, the role of Eladio Dieste's would be that of a lonely pioneer. Dieste's work was quite influential, but his innovations arose in a context of multiple technical experimentations, always interconnected. The contributions of the Colombian architects and engineers were fundamental, both those related to large buildings and those corresponding to small-scale buildings. 


\section{References}

1. Gulli R (1999) La huella de la construcción tabicada en la arquitectura de Le Corbusier in Las bóvedas de Guastavino en América, pp 87-112. Instituto Juan de Herrera, Madrid

2. Petrina A (1989) Entrevista a Eduardo Sacriste. In: Gutiérrez R et al Otra arquitectura argentina - Un camino alternativo. Escala. Bogotá

3. García J et al (2012) Arquitectura y construcción tabicada en torno a Eduardo Sacriste. Informes de la Con-strucción, vol 64, 525, pp 35-50. Enero-marzo CSIC, Madrid

4. Rodríguez JL (2008) Memorias de los años 50. Conversación con Francisco Pizano in Revista deAr-quitectura. Bogotá, vol 03(12/08), pp 16-29

5. Gutiérrez R (November 2002) Conversación con Francisco Pizano in Colección conversaciones de Arquitectura Co-lombiana, no 6, pp 97-119. Ediciones Uniandes, Bogotá

6. García E et al (1953) 1971 Viviendas Económicas Barrio Urdaneta Arbelaez. Revista PROA num, vol 71

7. Ortega A (1989) Prearquitectura del bienestar. Colección SomoSur. Escala, Bogotá

8. Vargas H (2008) El desarrollo de la edificación en concreto armado en Colombia: El caso de los pioneros D. Parma y G. González Zuleta (1945-1985) in DeArquitectura num. Bogotá, vol 04, pp 64-79

9. Goossens M (2014) Jorge Gaitán Cortés y la introducción del urbanismo moderno en Colombia. DEARQ - J Archit 14:210-223

10. Gutiérrez N (2011) La Casa de Jorge Gaitán Cortés en Bogotá. Instituto de Patrimonio Cultural, Bogotá, p 122

11. Sacriste E et al (1977) Casas con bóvedas. Espacio Editora, Buenos Aires

12. Vargas $\mathrm{H}$ et al (2015) The construction of thin concrete shell roofs in Colombia during the first half of the 20th Century: the work of Guillermo González Zuleta. 5th International Congress on Construction History, Chicago

13. García J, Magdalena F (2015) Equilibrium and Prefabrication. Prefabricated Brick Vaults in Latin America. In: Proceedings of the Fifth International Congress on Construction History, Chicago, vol 2, pp 153-160 